\title{
Transactions of the Royal Society
}

FIF'TH SERIES

\section{9}

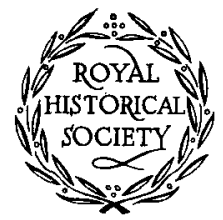

LONDON I 989 
(C) Royal Historical Society

\section{British Library Cataloguing in Publication Data}

Transactions of the Royal Historical Society.

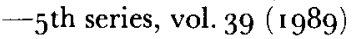

I. History-Periodicals

I. Royal Historical Society 905 D I

ISBN $0-86$ I $93^{-121-I}$

Made and printed in Great Britain by Butler \& Tanner Ltd, Frome and London 


\section{CONTENTS}

Presidential Address: Collective Mentalities in mid-Seven-

PAGE teenth-Century England: IV. Cross Currents: Neutrals, Trimmers and Others.

G. E. Aylmer.

Burial and Status in the Early Medieval West.

Edward James.

The Hapsburgs and the Hungarian Problem, I $790-1848$.

R.J. W. Evans.

Censorship, propaganda and public opinion: the case of the

Katyn graves, I 943 .

P. M. H. Bell.

The English Campaign against Luther in the 1520 (The Alexander Prize Essay.)

Richard Rex.

Anglo-Scottish Union and the Court of James I, I603-1625

(The Alexander Prize Essay, proxime accessit.)

Neil Cuddy.

Victorian Historians and the Royal Historical Society (The Prothero Lecture.)

J. W. Burrow.

Lord George Bentinck and the Protectionists: a lost cause? Angus Macintyre.

England and Northern Italy in the Early Fourteenth Century: the economic contrasts.

R. H. Britnell.

Report of Council ig88-89.

David Berry Prize 
Whitfield Prize

Officers and Council r 989

202

List of Fellows

205

List of Associates

264

List of Corresponding Fellows

269

Publications of the Royal Historical Society

$27 \mathrm{I}$

List of Titles

273 